\title{
Health Problems of the Leather Industry Workers
}

\author{
Iti Dubey* and Meenu Shrivastava
}

\author{
Department of Textiles \& Apparel Designing, College of Community and Applied Sciences, \\ MPUAT, Udaipur, India
}

*Corresponding author

\begin{abstract}
A B S T R A C T
Keywords

Occupational, Health hazards, Industry workers, Leather processing unit, Leather production unit, Combined leather units

Article Info

Accepted:

17 June 2019

Available Online:

10 July 2019

A healthy, productive and well-motivated workforce is the key agent for overall socioeconomic development. To assess the health of leather industry workers, selection of nine leather industries from Kanpur was done purposively by taking a sample of three units each from leather processing, leather production and combined leather units having both leather processing and production. Similarly, 90 workers were selected randomly, taking 30 each from selected three leather units to assess their health hazards. Structured interview schedule was used for data collection. Survey was carried out to collect the desired information. Frequency, percentage were used to analyze the data. Findings revealed that majority of the leather units were located in Jajmau area of Kanpur. Regarding profile of workers highlights that majority $(55.55 \%)$ of respondent were in the age group of 41-45 years, educated upto primary level (35.55\%). Majority of the respondents $(66.67 \%)$ had smoking habit. Researcher found that 73.33 percent respondents of leather processing units, 76.66 percent respondents of leather production units and 80 percent respondents of combine leather units had no past record of any health issues/illness. Majority of the respondents (76.67\%) family members did not suffer from any disease which is hereditary by nature.
\end{abstract}

\section{Introduction}

A healthy, productive and well-motivated workforce is the key agent for overall socioeconomic development. In addition, high-quality and productive work ensures healthy production of materials, goods and services and the consideration and practical implementation of the principles of sustainable development. For many adults the work environment is the most demanding environment in terms of physical, chemical, ergonomic or psychological stresses and physical workload. When work is associated with health hazards, it may cause occupational disease, is one of the multiple causes of other disease or may aggravate existing ill-health of non-occupational origin. In developing countries, where work is becoming increasingly mechanized, a number of work processes have been developed that treat workers as tools in production, putting their health and lives at risk. 


\section{Materials and Methods}

The consent of the Heads of the various leather processing and leather product industries was obtained for permitting their workers to participate in the study. On the basis of their willingness, a total sample of 90 leather industry workers was purposively selected taking 30 each from leather processing, leather production and leather processing and production industries.

For assessing the health hazards of leather Industry workers, an interview schedule was developed having both open and close ended questions. This tool was comprised of questions related to health hazards of workers at work place. The health profile of leather industry workers was assessed through personal observation during data collection with the respondents.

This section dealt with the past history of illness, previous occupation, smoking, drinking, tobacco habits and existing health problems.

\section{Results and Discussion}

\section{General profile of the respondents}

This section reveals the background details of the subjects. The respondents were studied for the age, education, job location, past history of illness, smoking, drinking, tobacco habits and existing health problems.

\section{Job location of the respondents}

The data in Table 1 shows the job location of the respondents. It can be seen that cent percent respondents of leather processing units were working in leather units located in Jajmau area of Kanpur, in leather production unit, majority of respondents $(66.67 \%)$ were working in Shyamnagar, Kanpur and remaining $(33.33 \%)$ in Karamcharinagar,
Kanpur and in combined leather units, majority $(66.67 \%)$ of respondents were working in leather units situated at Jajmau area and remaining in Magarwara, area.

\section{Age of the workers}

The data in Table 1 shows that majority $(55.55 \%)$ of respondent was in the age group of 41-45 years, 27.78 percent were between the age group of $45-50$ years, and remaining 16.67percent of them were above 35-40 years.

\section{Education}

The data in the Table 1 shows that majority $(35.55 \%)$ of respondent had education up to primary level followed by middle level $(26.67 \%)$ and graduation $(5.55 \%)$. It was also observed that 17.77 percent respondents were illiterate. 5.55 percent respondents had qualification up to graduation. Very few of them were having technical education $(2.22 \%)$ and diploma course $(1.11 \%)$.

\section{Work experience}

It is clear from the data in Table 1 that more than 40 percent of respondents each were having work experience of 10 years and 10 to 20 years respectively. Very few $(11.11 \%)$ of respondent had work experience of 20 to 30 years.

\section{Past health issues/illness}

Under past health issues/illness, the researcher studied smoking, drinking and tobacco chewing habits of the respondents working in different leather units. The data obtained has been presents as under.

\section{Smoking habit}

It was interesting to note that respondents of different subunits of leather industry had variability as far as their smoking habits are 
concerned. Table $2 \mathrm{a}, 2 \mathrm{~b}$ and $2 \mathrm{c}$ presents the data of Smoking habits of respondents working in leather processing, production and combined leather units.

\section{Smoking habits of leather processing unit workers}

Majority of the respondents $(73.33 \%)$ have smoking habit and out of these, 16.67 per cent of them started smoking from past 10 years while majority of them $(53.33 \%)$ were having this habit since last 20 years. Very few respondents $(3.33 \%)$ started smoking recently (last one year). Remaining 26.66 percent respondents were not having any smoking habit. Since the smoking is prohibited at the workplace, so the workers takeout time to smoke during break time. Majority of them (60\%) smoke daily and 13.33 percent workers smoke occasionally (Table 2a). It was found by the researcher that smoking was frequently done by the workers when they feel tired, had work related stress or family tension.

\section{Smoking habits of leather production unit workers}

It was revealed by the respondents that smoking is a part of their daily life. Data in Table $2 b$ depicts that majority of the respondents $(66.67 \%)$ had smoking habit and out of these, 33.33 per cent of them started smoking since last 20 years, 26.67 percent were having smoking habit since last 10 years and few of them $(6.67 \%)$ recently started smoking.

Remaining 33.33 percent respondents were not having any smoking habit. Since the smoking is prohibited at the workplace, most of the time workers tried to overcome this habit at workplace. Majority of them (40\%) smoke occasionally, only 16.67 percent workers smoke daily and 10 percent rarely. Therefore it can be said that scenario of "no smoking' is quite good in leather production unit workers as compared to processing unit workers.

\section{Smoking habits of combined leather unit workers}

Perusal of data in Table $2 \mathrm{c}$ shows that 60 per cent of the respondents had smoking habit and out of these, 33.33 percent respondents started smoking ten years back and remaining 26.67 percent 20 years back. A good number of respondents were not having any smoking habit. Majority of them (40\%) smoke daily and 13.33 percent occasionally and very few (6.67\%) smoke rarely.

\section{Drinking}

The researcher found that drinking habit was not very much prevalent among leather industry workers. Findings of the study showed that majority of the respondents (74.44\%) employed in leather units never drank alcohol. Those who drink alcohol reported that they had this habit from last10 to 15 years.

Data in Table 3 portrays that 13.33 percent respondents used to drink alcohol occasionally, 10 percent drink daily and 2.22 percent respondents rarely drink alcohol..

\section{Tobacco chewing habit}

Industry workers are often seen chewing tobacco. Researcher also observed at the time of data collection that leather industry workers were also fond of tobacco. Table 4 clearly indicates that majority of respondents (70\%) used to chew tobacco daily while 21.11 percent workers occasionally. Very few respondents $(8.89 \%)$ never chewed tobacco. When the researcher asked about the reason of tobacco chewing, it was told by them that it gives them relaxation calmness after long tiring working hours. 
Table.1 Frequency and percentage distribution of the respondents by their job location, age, education and work experience

\begin{tabular}{|c|c|c|c|c|c|c|c|c|}
\hline \multirow{3}{*}{ Location of units } & \multirow{2}{*}{\multicolumn{2}{|c|}{$\begin{array}{c}\text { Leather } \\
\text { processing } \\
\text { unit } \\
(\mathbf{n}=30)\end{array}$}} & \multirow{2}{*}{\multicolumn{2}{|c|}{$\begin{array}{c}\text { Leather } \\
\text { production } \\
\text { unit } \\
(\mathbf{n}=\mathbf{3 0})\end{array}$}} & \multirow{2}{*}{\multicolumn{2}{|c|}{$\begin{array}{l}\text { Combined } \\
\text { leather unit } \\
\text { (Leather } \\
\text { processing } \\
\text { \&production) } \\
(\mathbf{n}=30)\end{array}$}} & \multicolumn{2}{|c|}{$\mathrm{n}=90$} \\
\hline & & & & & & & & $\begin{array}{l}\text { otal } \\
\text { 90) }\end{array}$ \\
\hline & $\mathbf{f}$ & $\%$ & f & $\%$ & $\mathbf{f}$ & $\%$ & f & $\%$ \\
\hline Jajmau, Kanpur & 30 & 100 & & & 20 & 66.67 & 50 & 55.56 \\
\hline Shyamnagar, Kanpur & - & - & 20 & 66.67 & - & - & 20 & 22.22 \\
\hline $\begin{array}{l}\text { Karamcharinagar, } \\
\text { Kanpur nagar }\end{array}$ & - & - & 10 & 33.33 & - & - & 10 & 11.11 \\
\hline $\begin{array}{l}\text { Magarwara, unnao, } \\
\text { Kanpur }\end{array}$ & - & - & - & - & 10 & 33.33 & 10 & 11.11 \\
\hline Age of the workers & f & $\%$ & f & $\%$ & f & $\%$ & f & $\%$ \\
\hline $35-40$ & 4 & 13.33 & 7 & 23.33 & 4 & 1.2 & 15 & 16.67 \\
\hline $41-45$ & 17 & 56.67 & 14 & 46.67 & 19 & 5.7 & 50 & 55.55 \\
\hline $45-50$ & 9 & 30 & 9 & 30 & 7 & 2.1 & 25 & 27.78 \\
\hline Education & f & $\%$ & f & $\%$ & f & $\%$ & f & $\%$ \\
\hline Illiterate & 8 & 26.67 & 00 & 00 & 08 & 26.67 & 16 & 17.77 \\
\hline Up to middle & 6 & 20 & 03 & 10 & 15 & 50 & 24 & 26.67 \\
\hline Up to primary & 7 & 23.33 & 22 & 73.33 & 3 & 10 & 32 & 35.55 \\
\hline Up to metric & 3 & 10 & 00 & 00 & 00 & 00 & 3 & $\mathbf{3 . 3 3}$ \\
\hline Up to high school & 4 & 13.33 & 05 & 16.67 & 00 & 00 & 9 & 10 \\
\hline Graduate & 2 & 6.67 & 00 & 00 & 03 & 10 & 5 & 5.55 \\
\hline Technical education & - & - & - & - & 02 & 6.67 & 2 & 2.22 \\
\hline Diploma course & - & - & - & - & 01 & 3.33 & 1 & 1.11 \\
\hline Working experience & f & $\%$ & $\mathbf{f}$ & $\%$ & f & $\%$ & f & $\%$ \\
\hline 10 & 10 & 33.33 & 11 & 36.67 & 20 & 66.67 & 41 & 45.56 \\
\hline 10 to 20 & 18 & 60 & 13 & 43.33 & 8 & 26.67 & 39 & 43.33 \\
\hline 20 to 30 & 2 & 6.67 & 6 & 20 & 2 & 6.66 & 10 & 11.11 \\
\hline
\end{tabular}


Table.2a Percentage distribution of the respondents of leather processing unit by smoking habit

\begin{tabular}{|c|c|c|}
\hline Aspect/variable & Frequency(f) & Percentage (\%) \\
\hline \multicolumn{3}{|l|}{ Smoking habit } \\
\hline Yes & 22 & 73.33 \\
\hline No & 8 & 26.67 \\
\hline \multicolumn{3}{|c|}{ Past record of smoking } \\
\hline last 10 years & 5 & 16.67 \\
\hline 20 years & 16 & 53.33 \\
\hline recently & 1 & 3.33 \\
\hline \multicolumn{3}{|c|}{ Frequency of smoking } \\
\hline daily & 18 & 60.00 \\
\hline occasionally & 4 & 13.33 \\
\hline Rarely & 00 & 00 \\
\hline
\end{tabular}

Table.2b Percentage distribution of the respondents of leather production unit by smoking habit

\begin{tabular}{|l|c|c|}
\hline Aspect/variable & \multicolumn{2}{|c|}{ Frequency(f) } \\
\hline Smoking habit & 20 & Percentage (\%) \\
\hline Yes & 10 & 66.67 \\
\hline No & & 33.33 \\
\hline Past record of smoking & 8 & 26.67 \\
\hline last 10 years & 10 & 33.33 \\
\hline 20 years & 2 & 6.67 \\
\hline recently & & \\
\hline Frequency of smoking & 5 & 16.67 \\
\hline daily & 12 & 40.00 \\
\hline occasionally & 3 & 10.00 \\
\hline Rarely & & \\
\hline
\end{tabular}

Table.2 $\mathrm{c}$ Percentage distribution of the respondents of combined leather unit by smoking habit

\begin{tabular}{|c|c|c|}
\hline Aspect/variable & Frequency(f) & Percentage $(\%)$ \\
\hline \multicolumn{3}{|l|}{ Smoking habit } \\
\hline Yes & 18 & 60.00 \\
\hline No & 12 & 40.00 \\
\hline \multicolumn{3}{|c|}{ Past record of smoking } \\
\hline last 10 years & 10 & 33.33 \\
\hline 20 years & 8 & 26.67 \\
\hline recently & 00 & 00 \\
\hline \multicolumn{3}{|c|}{ Frequency of smoking } \\
\hline daily & 12 & 40.00 \\
\hline occasionally & 4 & 13.33 \\
\hline Rarely & 2 & 6.67 \\
\hline
\end{tabular}


Table.3 Frequency and percentage distribution of respondents by drinking habits

\begin{tabular}{|c|c|c|c|c|c|c|c|c|}
\hline \multicolumn{1}{|c|}{ Sub units } & \multicolumn{1}{|c|}{ Daily } & \multicolumn{2}{c|}{ Occasionally } & \multicolumn{2}{c|}{ Rarely } & \multicolumn{2}{c|}{ Never } \\
\cline { 2 - 10 } & $\mathbf{f}$ & $\mathbf{\%}$ & $\mathbf{f}$ & $\mathbf{\%}$ & $\mathbf{f}$ & $\mathbf{\%}$ & $\mathbf{f}$ & $\%$ \\
\hline Leather processing $(\mathbf{n}=\mathbf{3 0})$ & 05 & 16.66 & 05 & 16.66 & 01 & 3.33 & 19 & 63.33 \\
\hline Leather production $(\mathbf{n}=\mathbf{3 0})$ & 01 & 3.33 & 03 & 10 & 01 & 3.33 & 25 & 83.33 \\
\hline Combined leather unit $(\mathbf{n}=\mathbf{3 0})$ & 03 & 10 & 04 & 13.33 & - & - & 23 & 76.66 \\
\hline Total $(\boldsymbol{\%})$ & 9 & 10 & 12 & 13.33 & 2 & 2.22 & 67 & 74.44 \\
\hline
\end{tabular}

Table.4 Frequency and percentage distribution of respondents by tobacco chewing habit

\begin{tabular}{|c|c|c|c|c|c|c|c|c|}
\hline \multicolumn{1}{|c|}{ Sub units } & \multicolumn{1}{|c|}{ Daily } & \multicolumn{2}{c|}{ Occasionally } & \multicolumn{2}{c|}{ Rarely } & \multicolumn{2}{c|}{ Never } \\
\hline & $\mathbf{f}$ & $\mathbf{\%}$ & $\mathbf{f}$ & $\mathbf{\%}$ & $\mathbf{f}$ & $\mathbf{\%}$ & $\mathbf{f}$ & $\mathbf{\%}$ \\
\hline Leather processing $(\mathbf{n}=\mathbf{3 0})$ & 22 & 73.33 & 07 & 23.33 & 00 & 00 & 01 & 3.33 \\
\hline Leather production $(\mathbf{n}=\mathbf{3 0})$ & 17 & 56.66 & 08 & 26.66 & 00 & 00 & 05 & 16.66 \\
\hline Combined leather unit $(\mathbf{n}=\mathbf{3 0})$ & 24 & 80 & 04 & 13.33 & 00 & 00 & 02 & 6.66 \\
\hline Total (\%) & 63 & 70.00 & 19 & 21.11 & 00 & 00 & 8 & 8.89 \\
\hline
\end{tabular}

Table.5 Frequency and percentage distribution of respondents by past history of illness

\begin{tabular}{|c|c|c|c|c|c|c|c|c|}
\hline \multirow[t]{2}{*}{ Past illness } & \multicolumn{2}{|c|}{$\begin{array}{l}\text { Leather } \\
\text { processing unit } \\
(\mathbf{n}=\mathbf{3 0})\end{array}$} & \multicolumn{2}{|c|}{$\begin{array}{l}\text { Leather } \\
\text { production } \\
\text { unit } \\
(n=30)\end{array}$} & \multicolumn{2}{|c|}{$\begin{array}{l}\text { Leather } \\
\text { processing } \\
\text { \&production } \\
\text { both } \\
\text { unit(n=30) }\end{array}$} & \multicolumn{2}{|c|}{ Total } \\
\hline & f & $\%$ & f & $\%$ & f & $\%$ & f & $\%$ \\
\hline Yes & 8 & 26.67 & 7 & 23.33 & 6 & 20 & 26 & 28.88 \\
\hline No & 22 & 73.33 & 23 & 76.66 & 24 & 80 & 64 & 71.11 \\
\hline
\end{tabular}

$\mathrm{n}=90$

Table.6 Frequency and percentage distribution of respondents by family health problems

\begin{tabular}{|c|c|c|c|c|c|c|c|c|}
\hline \multirow[t]{2}{*}{$\begin{array}{c}\text { Aspect/variabl } \\
\text { e }\end{array}$} & \multicolumn{2}{|c|}{$\begin{array}{l}\text { Leather } \\
\text { processing unit } \\
(n=30)\end{array}$} & \multicolumn{2}{|c|}{$\begin{array}{l}\text { Leather } \\
\text { production unit } \\
(\mathrm{n}=30)\end{array}$} & \multicolumn{2}{|c|}{$\begin{array}{l}\text { Leather processing } \\
\text { \&production both } \\
\text { unit } \\
(\mathbf{n}=30)\end{array}$} & \multicolumn{2}{|c|}{$\begin{array}{c}\text { Total } \\
\text { Percentage } \\
(\%)\end{array}$} \\
\hline & f & $\%$ & $\mathbf{f}$ & $\%$ & $\mathbf{f}$ & $\%$ & f & $\%$ \\
\hline No Problem & 22 & 73.33 & 23 & 76.66 & 24 & 80 & 69 & 76.67 \\
\hline Cough & 3 & 10 & 2 & 6.67 & 6 & 20.00 & 11 & 12.22 \\
\hline B.P. & - & - & 1 & 3.33 & - & - & 1 & 1.11 \\
\hline T.B. & - & - & 2 & 6.67 & - & - & 2 & 2.22 \\
\hline Throat & 2 & 6.67 & 1 & 3.33 & - & -- & 3 & $\mathbf{3 . 3 3}$ \\
\hline Asthma & 2 & 6.67 & 1 & 3.33 & - & - & 3 & 3.33 \\
\hline Cancer & - & - & - & - & - & - & - & - \\
\hline Skin Disease & 1 & $\mathbf{3 . 3 3}$ & - & - & - & - & 1 & 1.11 \\
\hline
\end{tabular}


Table.7 Percentage distribution of respondents by health problems faced at work place in leather unit

\begin{tabular}{|c|c|c|c|c|c|c|c|c|c|c|c|c|c|c|c|c|}
\hline \multirow[t]{2}{*}{$\begin{array}{c}\text { Health } \\
\text { Problems }\end{array}$} & \multicolumn{5}{|c|}{$\begin{array}{l}\text { Leather processing unit } \\
\qquad(\mathbf{n}=\mathbf{3 0})\end{array}$} & \multicolumn{5}{|c|}{$\begin{array}{l}\text { Leather production unit } \\
\qquad(\mathrm{n}=\mathbf{3 0})\end{array}$} & \multicolumn{5}{|c|}{$\begin{array}{l}\text { Leather processing and production } \\
\text { both units } \\
(\mathbf{n}=\mathbf{3 0})\end{array}$} & \multirow[t]{2}{*}{$\begin{array}{c}\text { Total } \\
(\%)\end{array}$} \\
\hline & D & W & $\mathbf{F}$ & $\mathbf{M}$ & $\mathbf{T}(\%)$ & D & W & $\mathbf{F}$ & $\mathbf{M}$ & $\mathrm{T}(\%)$ & D & $\mathbf{W}$ & $\mathbf{F}$ & $\mathbf{M}$ & $\mathbf{T}(\%)$ & \\
\hline Headache & 90 & 6.67 & 3.33 & - & 100 & 83.33 & $\begin{array}{l}13.3 \\
3\end{array}$ & 3.33 & - & 100 & 93.33 & 3.33 & 3.33 & - & 73.33 & 88.88 \\
\hline $\begin{array}{l}\text { Itching in } \\
\text { skin }\end{array}$ & $\begin{array}{c}56.6 \\
7\end{array}$ & 40 & 00 & - & 96.67 & 26.67 & $\begin{array}{c}26.6 \\
7\end{array}$ & 16.67 & 3.33 & 66.67 & 6.67 & 6.67 & 6.67 & - & 20 & 61.11 \\
\hline Fatigue & $\begin{array}{l}33.3 \\
3\end{array}$ & 6.66 & - & 23.33 & 73.32 & 46.67 & $\begin{array}{c}23.3 \\
3\end{array}$ & - & - & 70 & 73.33 & 13.33 & 6.67 & - & 93.33 & 71.11 \\
\hline Nausea & - & - & 43.33 & 26.67 & 73.34 & - & 40 & 16.67 & - & 56.67 & - & 13.33 & 6.67 & - & 20 & 44.67 \\
\hline $\begin{array}{l}\text { Throat } \\
\text { infection }\end{array}$ & & 20 & 30 & 6.66 & 56.66 & 30 & - & 26.76 & - & 56.67 & - & 33.33 & 23.33 & - & 56.66 & 52.89 \\
\hline Sneezing & 20 & 30 & - & - & 50 & 20 & - & 16.67 & - & 36.67 & 40 & - & 6.67 & - & 46.67 & 41.55 \\
\hline $\begin{array}{l}\text { Itching in } \\
\text { eye }\end{array}$ & - & - & 56.67 & - & 56.67 & & & & 6.67 & 6.67 & - & - & - & 13.33 & 13.33 & 24.88 \\
\hline
\end{tabular}


Fig.1 Percentage distribution of respondents about health problems faced by them while working in leather processing / and production unit

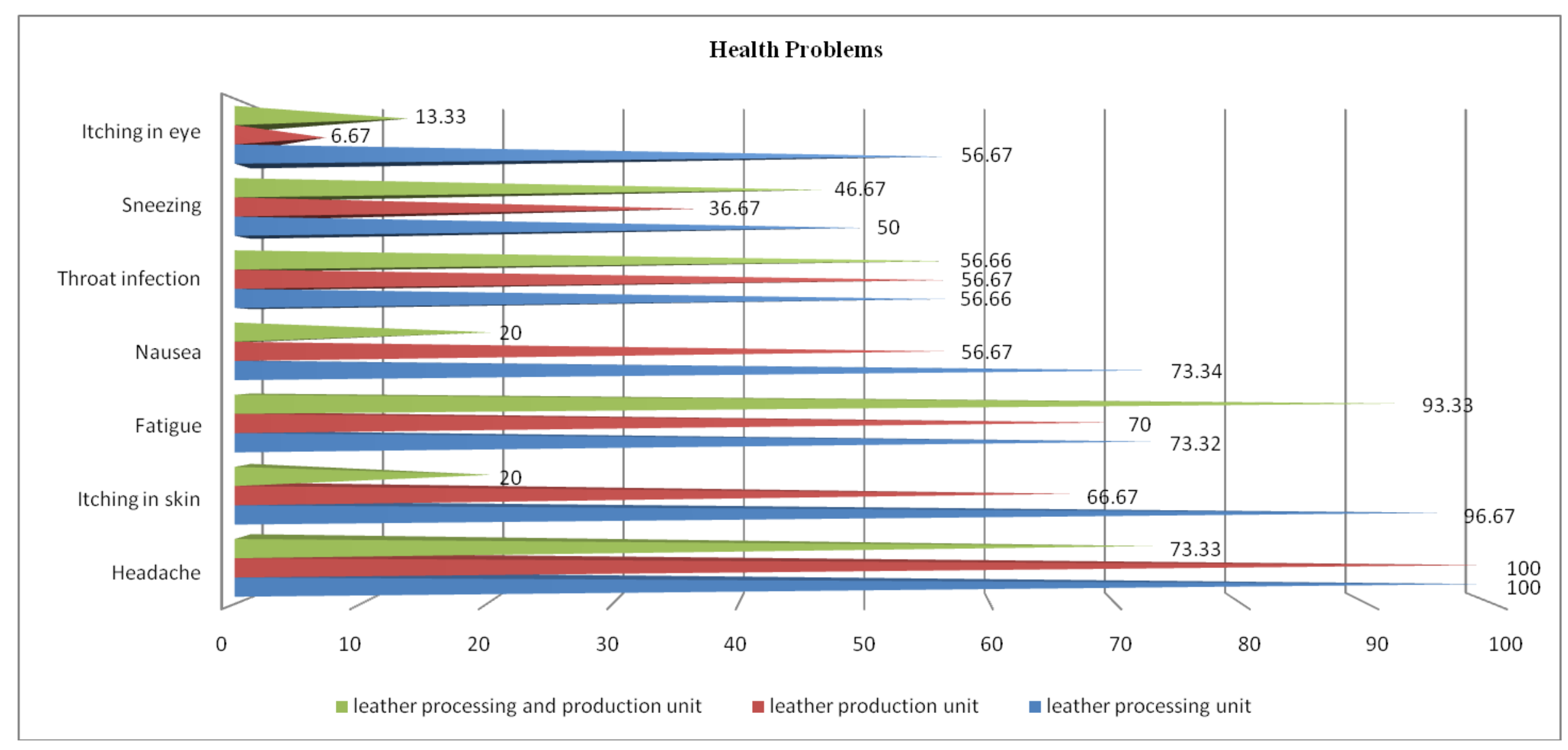


It was also reported by them that this tobacco chewing habit was developed in them, when they started earnings for their family.

\section{Health problems /past history of illness}

Table 5 highlights the data regarding health problems of respondents before joining leather industry. Researcher found that 73.33 percent respondents of leather processing units, 76.66 percent respondents of leather production units and 80 percent respondents of combine leather units had no past record of any health issues/illness. It was reported by the respondents of the leather units that health problems began after they started working in the unit.

\section{Family health problems}

In response to the question asked by the researcher regarding family health problems, data in Table 6 revealed by majority of the respondents $(76.67 \%)$ that their family members did not suffer from any disease which is hereditary by nature. Very few respondents family members suffered from the problem of blood pressure and skin disease each (1.11\%) and T.B. (2.22\%). The problem of cough was found in 12.22 percent respondents family member followed by an equal percentage $(3.33 \%)$ of the respondents family members who suffered from asthma and throat related problems.

\section{Health problems faced at work place}

Leather units in present research consists of three types of industries, engaged in leather processing only, leather production only and also the combined leather units in which both leather processing and production work is carried out.

The selected respondents (workers) from all the three types of leather units were personally observed and interviewed by the researcher to get first-hand information about the health problems faced by them at work place due to continuous exposure of harsh chemicals and other substances used in different subunits to convert raw hides/skin into semi-finished or finished leather form.

Data in Table 7 and Figure 1 clearly depicts that in all the units, headache and fatigue were the common problem among workers. Cent percent respondents of leather processing and leather production units were suffering from headache, it was more pronounced in respondents $(73.33 \%)$ of combined leather units also. The main cause of headache and fatigue as mentioned by the respondents were continuous working for 8 hours amidst loud noise of equipment's and machinery when used.

Majority of respondents working in leather processing units $(96.67 \%)$, production unit $(66.67 \%)$ and also in combined leather unit $(61.11 \%)$ had the problem of itching of skin.

It was also found that 73.34 percent of respondents suffered from nausea in processing units followed by respondents of production unit $(56.67 \%)$ due to foul odour of hides/skin, hot vapours and fumes of chemicals released during various leather processing operations of converting raw hides into wet blue.

The problem of itching of eyes was most widespread in processing unit $(56.67 \%)$ for the reason that they work for long hours and had and chemical exposure.

This problem was of less concerned in respondents of combined units $(13.33 \%)$ and very less (6.67) in respondents of leather production unit. The problem of frequent throat infection was faced by more than 50 percent respondents of all the selected leather 
units. The reasons behind this may be inhalation of fumes of chemicals used in these units.

The findings are in conformity with Koka (2012) who studied the health hazards of textile processing industries of Pali in Rajasthan. Findings revealed that majority of respondents suffered from various physical ailments related to lungs, eyes, skin and ear. Half of the respondents reported watering of eye due to the gases evolved by chemicals during various processes. Exposure of toxic chemicals causes various skin and respiratory problems among respondents.

\section{References}

Dubey, I. 2019. Occupational health hazards of leather industry workers of Kanpur. M.Sc. thesis in Department of Textile and Apparel Designing, College of Home science, MaharanaPratap University of Agriculture and Technology, Udaipur.

Koka, V. 2012. Occupational health hazards of textile workers of Pali district. Ph.D thesis in Department of Textile and Apparel Designing, College of Home science, Maharana Pratap University of Agriculture and Technology, Udaipur.

\section{How to cite this article:}

Iti Dubey and Meenu Shrivastava. 2019. Health Problems of the Leather Industry Workers. Int.J.Curr.Microbiol.App.Sci. 8(07): 2089-2107. doi: https://doi.org/10.20546/ijcmas.2019.807.252 